\title{
Analysis of virulence diversity of 73 Helicobacter pylori strains isolated in Guizhou province, China
}

\author{
LIN YIN $^{1,2}$, FANG LIU ${ }^{1}$, CHANGCHENG GUO $^{1}$, QIONG WANG ${ }^{1}$, KE PAN $^{3}$, \\ LIANGBI XU ${ }^{4}$, YAN XIONG ${ }^{5}$, YINGTING CHEN ${ }^{4}$ and ZHENGHONG CHEN ${ }^{1}$ \\ ${ }^{1}$ Department of Microbiology, School of Basic Medical Science, Guizhou Medical University, \\ Key Laboratory of Medical Microbiology and Parasitology of Guizhou Province, Guiyang, Guizhou 550025; \\ ${ }^{2}$ Department of Clinical Laboratory, The Second People's Hospital of Hunan Province, Changsha, Hunan 410007; \\ ${ }^{3}$ Department of Gastrointestinal Medicine, The People's Hospital of Qiannan Autonomous Prefecture, \\ Duyun, Guizhou 558000; ${ }^{4}$ Department of Gastrointestinal Medicine, The First Affiliated Hospital of \\ Guizhou Medical University, Guiyang, Guizhou 550004; ${ }^{5}$ Department of Gastrointestinal Medicine, \\ Guiyang Children's Hospital, Guiyang, Guizhou 550000, P.R. China
}

Received December 12, 2017; Accepted August 7, 2018

DOI: $10.3892 / \mathrm{mmr} .2018 .9462$

\begin{abstract}
The present study aimed to investigate the virulence diversity of Helicobacter pylori (H. pylori) in major ethnic groups residing in Guizhou province, China, and its association with clinical outcomes. Gastric mucosal biopsies were collected from the pylorus of patients with gastrointestinal disorders. $H$. pylori was identified by colonial morphology, Gram staining, a urease test and $H$.pylori-specific $16 S r R N A$ gene fragment PCR amplification. DNA was extracted from pure culture and used for virulence gene analysis. The cytotoxin associated gene A (cagA), vacuolating cytotoxin $\mathrm{A}$ ( $\operatorname{vacA}$ ) and induced by contact with epithelium gene A (iceA) genes were analyzed by polymerase chain reaction analysis. The cagA gene was further analyzed through sequencing of the $\mathrm{C}$-terminal region containing EPIYA motifs, and phylogenetic analysis of the cag A C-terminal variable region was performed using MEGA 6.0 software. In the present study, $73 \mathrm{H}$. pylori strains were isolated from clinical samples. cagA genotypes were detected in all strains, namely cag $\mathrm{A}-\mathrm{AB}$, $-\mathrm{ABC},-\mathrm{ABD}$ and -BD genotypes were found in five (6.85\%), three (4.11\%), $63(86.30 \%)$ and two (2.74\%) isolates, respectively.
\end{abstract}

Correspondence to: Professor Zhenghong Chen, Department of Microbiology, School of Basic Medical Science, Guizhou Medical University, Key Laboratory of Medical Microbiology and Parasitology of Guizhou Province, 1 South Dongqing Road, Guiyang, Guizhou 550025, P.R. China

E-mail: chenzhenghong@gmc.edu.cn

Abbreviations: H. pylori, Helicobacter pylori; cagA, cytotoxin associated gene A; vacA, vacuolating cytotoxin A; iceA, induced by contact with epithelium gene $\mathrm{A}$; PCR, polymerase chain reaction

Key words: Helicobacter pylori, virulence, cytotoxin associated gene A, vacuolating cytotoxin A, induced by contact with epithelium gene A
Phylogenetic analysis showed that there was a clustering association between the cag A-AB and cagA-ABC genotypes, and between the cagA-ABD and cagA-BD genotypes. In terms of the frequency of the four EPIYA or EPIYA-like motifs, the most predominant was EPIYA (92.92\%), followed by EPIYT (3.77\%), ESIYA (2.83\%) and ESIYT (0.47\%). The predominant vacA genotype was $\mathrm{slc} / \mathrm{m} 2(65.75 \%)$, and the predominant iceA genotype was iceA1 (79.45\%). There were no associations between the H. pylori cagA, vacA or iceA genotypes and clinical outcomes. No significant difference was found in the distribution of these genotypes according to the age, ethnicity or location of residence of patients. In conclusion, H. pylori isolated from patients in Guizhou region, China, showed a unique genotype, which was mainly East Asia-type cagA (ABD), vacA s1c/m2 genotype or iceA1-postiive. These results provide important information on the distribution of $H$. pylori virulence genotypes in Guizhou province, China.

\section{Introduction}

Helicobacter pylori (H. pylori) is a Gram-negative, spiral-shaped, microaerophilic bacterium that colonizes the human gastric mucosa (1). H. pylori infection can cause chronic gastritis, peptic ulcer disease, gastric carcinoma and mucosa-associated lymphoid tissue lymphoma (2-4). More than half of the world's population is infected with H.pylori (5). However, the majority of infected individuals remain asymptomatic. There is an interplay between host genetic susceptibility, environmental factors and bacterial virulence factors, which influences the outcome of $H$. pylori-associated diseases (6-8). Polymorphisms of several virulence genes, including cytotoxin-associated gene A (cagA), vacuolating toxin A (vacA), induced by contact with epithelium gene A (iceA), blood group antigen binding adhesin and duodenal ulcer promoting gene $\mathrm{A}$ are considered to increase the risk for the development of upper gastrointestinal diseases (9). Among these genes, cagA and vacA have been investigated extensively. 
CagA is an oncogenic protein, and is a major virulence factor associated with gastric cancer $(10,11)$. CagA is injected into host epithelial cells via the type IV secretion system encoded by cag pathogenicity island (cagPAI) following $H$. pylori infection (12). CagA undergoes phosphorylation at its EPIYA motif by the Abl and Src family tyrosine kinases (13). Once tyrosine is phosphorylated, the cagA EPIYA motifs serve as a recognition site for Src homology phosphotyrosine phosphatase 2 (SHP2), and activate an intracellular signal transduction pathway that leads to cytoskeletal rearrangement and cell elongation, known as the 'hummingbird' phenotype (14). This increases the risk of developing precancerous lesions (15).

The EPIYA motif is located within the C-terminal of cagA, and is formed of the conserved amino-acid residues Glu-Pro-Ile-Tyr-Ala. EPIYA can be further classified into four types of motif: EPIYA-A, -B, -C and -D, based on the flanking amino acid sequences (16). H. pylori is classified as East Asian-type cagA and western-type cagA, according to the composition of the EPIYA-A, $-\mathrm{B},-\mathrm{C}$ and D motifs. The western-type cagA is mainly cag A-ABC, whereas the East Asian-type is mainly cagA-ABD (17). The EPIYA-C and EPIYA-D motifs act as phosphorylation sites for SHP-2 (18). The EPIYA-D segment exhibits a greater degree of tyrosine phosphorylation and higher binding affinity to SHP2 than the EPIYA-C segment and shows higher virulence (2). East Asian-type cagA is associated with a higher risk of peptic ulcers or gastric cancer within the same geographical area compared with western-type cagA (19). Epidemiological surveys show that $\sim 50-60 \%$ of $H$. pylori strains in western countries contain the cagA gene, which increases the risk of peptic ulcers and gastric cancer (20). Although $90-100 \%$ of $H$. pylori strains in East Asian countries are cagA-positive, cagA-positive strains may not be associated with clinical outcomes (21).

VacA is a pore-forming toxin, which has several effects on epithelial cells. In addition to inducing vacuolation (22), vacA can induce membrane channel formation, which leads to the release of cytochrome $c$ from mitochondria and results in apoptosis (23). Notably, it has immunomodulatory effects through inhibiting T-cell activation and proliferation $(6,19)$. There are four sequence diversity regions of vacA closely associated with $H$. pylori vacuolating activity, namely signal region (s-), deletion region (d-), intermediate region (i-) and middle region (m-) (4). The cytotoxicity of vacA is determined by variability in the structure of the vacA gene (24). The s- and m- regions of vacA are the two main polymorphic regions and serve as markers of $H$. pylori virulence and the risk of associated diseases (25).

Several studies have shown that iceA has two main allelic variants, namely iceA1 and iceA2 (26). The expression of iceA1 is upregulated upon contact between $H$. pylori and human epithelial cells. The iceA1 genotype is linked with enhanced mucosa interleukin-8 expression and acute inflammation (27). Epidemiological data shows that the geographical distribution of iceA genotypes varies. The iceA1 strains mainly occur in Japan and South Korea, whereas iceA2 strains are predominant in the United States and Columbia (28). A previous meta-analysis showed that the prevalence of iceA1 was significantly higher in East Asian countries than in western countries, whereas the prevalence of iceA2 was higher in western countries than in East Asian countries (26). Functionally, the iceA1 genotype is associated with peptic ulcers (29) and the
iceA2 genotype with the occurrence of chronic gastritis (28). To date, the majority of studies have shown that the iceA gene is another virulence gene independent of cagA and vacA (30).

Guizhou, a province located in southwest China, is a multi-ethnic society. In particular, those in Qiannan, Buyei and Miao Autonomous Prefecture have a particular lifestyle and are different from other ethnic groups. The individuals living here often use herbal medicine to treat diseases, including stomach disorders. As Xie et al (31) reported, such traditional medicine may have an effect on bacteria in the stomach,including H.pylori. Although investigations on the role of $H$. pylori virulence cagA and vacA genotypes have been performed worldwide, the associations between $H$. pylori virulence genotype and gastroduodenal diseases, ethnicity or economic conditions in Guizhou province remain to be fully elucidated. Therefore, the present study aimed to investigate these associations, which may facilitate diagnosis and therapeutic strategies for gastroduodenal diseases.

\section{Materials and methods}

Clinical samples. Gastric pylorus mucosa biopsy samples were obtained by endoscopy from patients with gastric disorders at the First Affiliated Hospital of Guizhou Medical University (Guizhou, China) and the People's Hospital of Qiannan Autonomous Prefecture (Duyun, China) between January and December 2016. Clinicopathological data were collected, and written informed consent was obtained from all patients. Patients with the following conditions were excluded from the present study: A tendency to bleed, lactating or pregnant women, the inability to undergo surgery to the UGI tract, and severe cardiovascular or hepatic disease. All protocols were approved by the Ethical Committee of the First Affiliated hospital of Guizhou Medical University. All procedures contributing to the study complied with the Declaration of Helsinki.

H. pylori isolation and bacterial DNA extract. Gastric mucosa samples were cut into small sections, homogenized and smeared on the surface of Brain Heart Infusion agar with $10 \%$ sheep blood (Qingdao Hope Biol-Technology Co., Ltd., Qingdao, China) and antibiotic supplement (H.pylori selective supplement, Thermo Fisher Scientific Oxoid, Ltd., Basingstoke, UK). The plates were incubated at $37^{\circ} \mathrm{C}$ for 3-5 days under microaerophilic conditions. H. pylori was identified through colonial morphology, Gram staining, a urease test, and $H$. pylori-specific $16 S$ rRNA gene fragment polymerase chain reaction (PCR) amplification. The colony of $H$. pylori was smooth and translucent, and the morphology was Gram-negative with spiral-shaped bacilli. The confirmed colonies were subcultured to single colonies on fresh medium. Following incubation at $37^{\circ} \mathrm{C}$ for 3-5 days, the colonies were subjected to DNA extraction using an Ezup column bacteria genomic DNA purification kit (Sangon Biotech Co., Ltd., Shanghai, China), according to the manufacturer's protocol.

PCR amplification and sequencing. PCR assays to amplify cagA and sequence its $\mathrm{C}$-terminal region were performed according to the report by Sicinschi et al (14). Primers (Sangon Biotech Co., Ltd., Shanghai, China) used for amplification of 


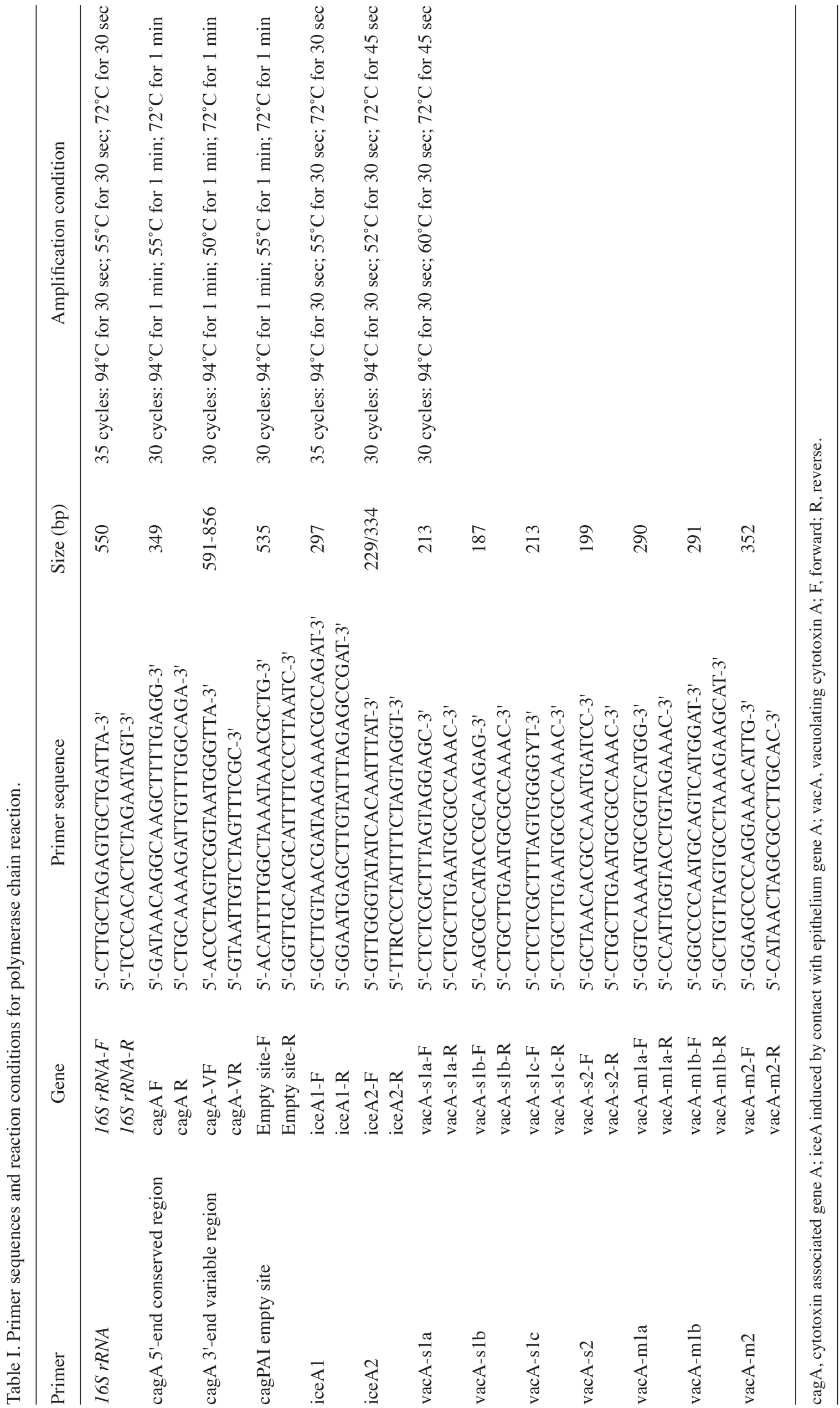


Table II. Demographic characteristics of patients.

\begin{tabular}{|c|c|c|c|}
\hline Characteristic & Patients (n) & Age $\left(\right.$ years) ${ }^{\mathrm{a}}$ & Range \\
\hline \multicolumn{4}{|l|}{ Sex } \\
\hline Male & 41 & $38.85 \pm 19.43$ & $3-80$ \\
\hline Female & 32 & $39.94 \pm 18.93$ & $4-66$ \\
\hline \multicolumn{4}{|l|}{ Ethnicity } \\
\hline Han & 60 & $40.68 \pm 19.64$ & $3-80$ \\
\hline \multicolumn{4}{|l|}{ Ethnic minority } \\
\hline Miao & 4 & $25.75 \pm 19.45$ & $7-44$ \\
\hline Dong & 2 & $23 \pm 22.63$ & $7-39$ \\
\hline Tujia & 2 & $36.5 \pm 16.26$ & $25-48$ \\
\hline Buyi & 2 & $42.5 \pm 0.71$ & $42-43$ \\
\hline Bai & 2 & $36.5 \pm 2.12$ & $35-38$ \\
\hline $\mathrm{Yi}$ & 1 & 50 & - \\
\hline \multicolumn{4}{|l|}{ Place of residence } \\
\hline Guiyang city & 60 & $37.97 \pm 20.73$ & $3-80$ \\
\hline Qiannan autonomous prefecture & 13 & $45.62 \pm 4.68$ & $38-53$ \\
\hline Urban & 31 & $42.19 \pm 21.19$ & $3-80$ \\
\hline Suburban & 42 & $36.41 \pm 19.49$ & 4-72 \\
\hline \multicolumn{4}{|l|}{ Clinical disease } \\
\hline Gastritis & 54 & $38.11 \pm 20.34$ & $3-80$ \\
\hline Peptic ulcer & 19 & $42.79 \pm 14.90$ & $9-60$ \\
\hline
\end{tabular}

${ }^{\mathrm{a}} \mathrm{Age}$ is expressed as the mean \pm standard deviation.

the cagA, vacA and iceA genes in the present study are shown in Table I. Following DNA extraction from pure culture of H. Pylori isolates as previously mentioned, PCR assays were performed in a volume of $26 \mu 1$ containing $1 \mu 1$ forward primer, $1 \mu \mathrm{l}$ reverse primer, $4 \mu \mathrm{l}$ genomic DNA, $13 \mu \mathrm{l} 2 \mathrm{X}$ Taq PCR Master Mix (Beijing Solarbio Science and Technology Co., Ltd., Beijing, China) and $7 \mu \mathrm{lddH_{2 }}$ O. Table I summarizes the expected size of the PCR products and cycling conditions for cagA gene, vacA subtype gene and iceA allelic genes (14,32-34). All runs included one negative $\left(\mathrm{ddH}_{2} \mathrm{O}\right)$ and one positive (NCTC 11637 or H. pylori 26695) DNA control, and DNA ladder markers (Tiangen Biotech Co., Ltd., Beijing, China). A total of $6 \mu \mathrm{l}$ of amplified PCR products was then resolved by electrophoresis on $2 \%$ agarose gels run in acetate EDTA buffer, and stained with ethidium bromide. The PCR product was visualized under ultraviolet light. The cagA C-terminal PCR products were sent to Sangon Biotech Co., Ltd. for Sanger sequencing. The gene sequences were translated into amino acid sequences using Bioedit software (version 7.1.3.0; https://www.bioedit.com/). Phylogenetic tree cluster analysis of cagA carboxyl terminal variable region was constructed using MEGA software (version 6.0; https://www. megasoftware.net/megamac.php), based on neighbor joining. The control strain NCTC 11637 was obtained from the State Key Laboratory of Infectious Disease Prevention and Control (National Institute for Communicable Disease Control and Prevention, Beijing, China), and the amino acid sequences of H. pylori 26695 were obtained from GenBank (https://www. ncbi.nlm.nih.gov/nuccore/CP003904.1).
Statistical analysis. All data were analysed using SPSS 19.0 (IBM SPSS, Armonk, NY, USA), $\chi^{2}$ test and Fisher's exact test were used for the analysis of categorical data. $\mathrm{P}<0.05$ was considered to indicate a statistically significant difference.

\section{Results}

Clinical and pathological information. A total of $73 \mathrm{H}$. pylori strains were isolated from patients with upper gastroduodenal disorders. The demographics of these patients are shown in Table II. Among the 73 cases, 41 were men with a mean age of $38.85 \pm 19.43$ years, and range of 3-80 years, and 32 were women with a mean age of $39.94 \pm 18.93$ years, and range of 4-66. A total of 60 strains were isolated from Han groups, and 13 from other minority ethnic groups, including Miao, Dong, Tujia, Buyi, Bai and Yi groups. A total of 60 strains were isolated from Guiyang city, and 13 from Qiannan autonomous prefecture. A total of 31 cases were from urban populations, and 42 were from suburban populations. Finally, 54 strains were isolated from patients with gastritis and 19 from patients with peptic ulcers, the latter comprising eight with gastric ulcer and 11 with duodenal ulcer. PCR products of $550 \mathrm{bp}$ represented $H$. pylori-specific $16 S$ rRNA, as shown in Fig. $1 \mathrm{~A}$.

Polymorphism of cagA. The cagA N-terminal conserved region (cagA 5'-end) and $\mathrm{C}$-terminal variable region (cagA 3 '-end) were amplified by PCR using the specific primers (Table I). PCR products of 349 bp represented the 
Table III. Distribution of cagA genotypes in Guizhou province.

\begin{tabular}{lccc}
\hline Genotype & $\mathrm{n}(\%)$ & Guiyang city strains $(\mathrm{n})$ & Qiannan autonomous prefecture strains (n) \\
\hline Western-type cagA-AB & $5(6.85)$ & 5 & 0 \\
Western-type cagA-ABC & $3(4.11)$ & 3 & 0 \\
East Asia-type cagA-ABD & $63(86.30)$ & 50 & 13 \\
East Asia-type cagA-BD & $2(2.74)$ & 2 & 0 \\
vacA s1c/m1b & $18(24.66)$ & 13 & 5 \\
vacA s1c/m2 & $48(65.75)$ & 61 & 7 \\
vacA s1c/m1b/m2 & $7(9.59)$ & 49 & 1 \\
iceA1 & $58(79.45)$ & 1 & 9 \\
iceA2 & $2(2.74)$ & 10 & 1 \\
iceA1+iceA2 & $13(17.81)$ & 6 & 3 \\
\hline
\end{tabular}

cagA, cytotoxin associated gene A; vacA, vacuolating cytotoxin A; iceA, induced by contact with epithelium gene A.

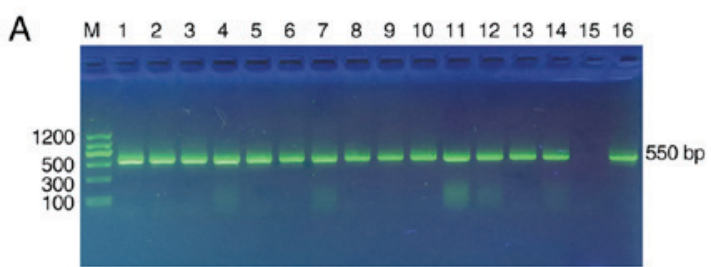

B

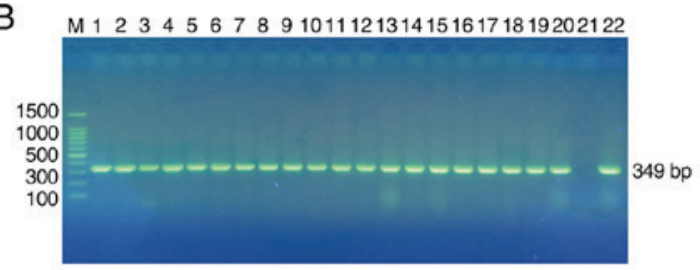

C

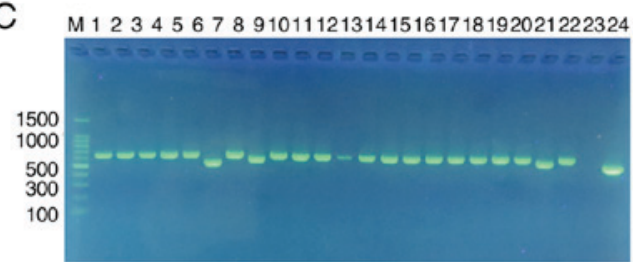

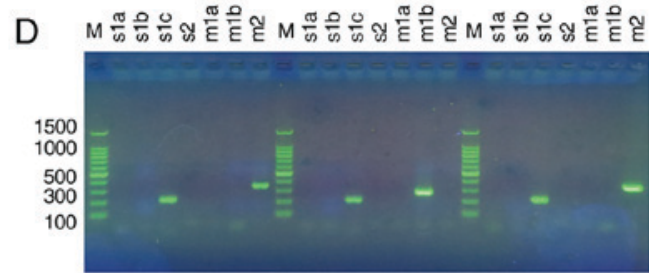

$\mathrm{E}$

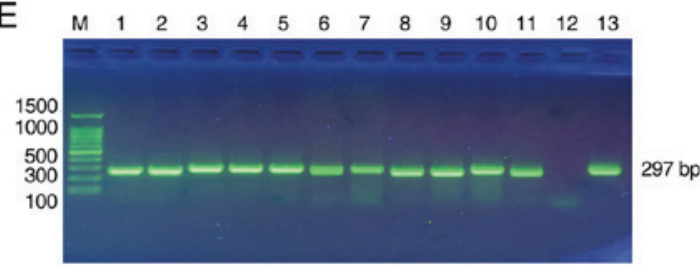

$\mathrm{F}$

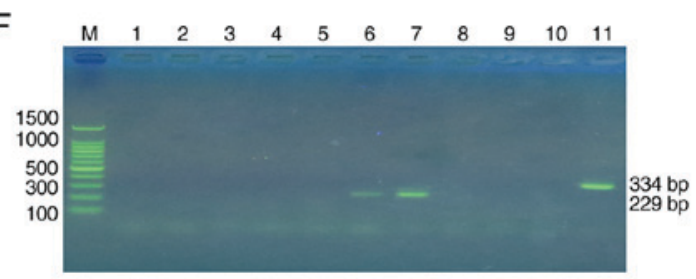

Figure 1. PCR amplification of H.pylori cagA, vacA and iceA genes. (A) Gel electrophoresis of genus-specific $16 S$ rRNA PCR products from $H$. pylori isolates. M, Marker II; 1-14, positive sample for $16 \operatorname{Sr} R N A$ PCR; 15, negative control; 16, positive control (NCTC 11637). (B) Gel electrophoresis of clinical samples with different cagA N-terminals. M, 100 bp DNA ladder marker; 1-20, clinical sample; 23, negative control; 24, positive control (NCTC 11637). (C) Gel electrophoresis of clinical samples with different cagA EPIYA patterns. M, 100 bp DNA ladder marker; 1-22, clinical sample; 23, negative control; 24, positive control (NCTC 11637). (D) Gel electrophoresis of H. pylori genotyping of vacA alleles. M, 100 bp DNA ladder marker; s1a, s1b, slc and s2, vacA signal region; m1a, mlb and $\mathrm{m} 2$, vacA middle region. (E) Gel electrophoresis of $H$. pylori genotyping of iceA1 alleles. M, 100 bp DNA ladder marker; 1-11, clinical sample; 12, negative control; 13, positive control (H. pylori 26695). (F) Gel electrophoresis of H. pylori genotyping of iceA2 alleles. M, 100 bp DNA ladder marker; 1-5 and 8-9, negative clinical sample; 6-7, positive clinical sample (iceA2-229 bp); 10, negative control; 11, positive control (iceA2-334 bp). H. pylori, Helicobacter pylori; cagA, cytotoxin associated gene A; vacA, vacuolating cytotoxin A; iceA induced by contact with epithelium gene A; PCR, polymerase chain reaction.

5 '-end fragments, as shown in Fig. 1B, and were present in all H. pylori isolates ( $\mathrm{n}=73,100 \%)$. CagPAI empty site PCR produced negative results in all of these strains, indicating the absence of cagA-negative strains in the mixture. PCR products within the range of 450-650 bp represented the 3 '-end fragments, as shown in Fig. 1C. All H. pylori isolates were found to contain the 3 '-end variable region expressing various EPIYA motifs. Notably, four distinct PCR products (500, 600, 610 and $550 \mathrm{bp}$ amplicons) were obtained from the various $H$. pylori isolates (Fig. 1C).
Polymorphism of vacA. The vacA gene polymorphism was also analyzed. The vacA gene has variation regions including signal (s-) and middle (m-) regions (24). Usually, alleles are further divided into sub-alleles, including s1a, s1b, s1c, s2, m1a, m1b and $\mathrm{m} 2$ (34). The H. pylori isolates were screened for all sub-alleles by the PCR assay, as shown in Fig. 1D. vacA $\mathrm{s} 1 \mathrm{c} / \mathrm{m} 1 \mathrm{~b}$ and $\mathrm{s} 1 \mathrm{c} / \mathrm{m} 2$ genotypes were identified in 24.66 and $65.75 \%$, respectively, whereas the $\mathrm{s} 1 \mathrm{c} / \mathrm{m} 1 \mathrm{~b} / \mathrm{m} 2$ mixed genotype was only identified in $9.59 \%$, as shown in Table III. The distribution of vacA genotypes in Guizhou province is shown 
Table IV. Distribution of virulence genotypes by clinical disease and age of patients.

\begin{tabular}{|c|c|c|c|c|c|c|}
\hline Genotype & Gastritis $(n=54)$ & Peptic ulcer $(n=19)$ & P-value & Age $<18$ years $(n=16)$ & Age $>18$ years $(n=57)$ & P-value \\
\hline $\operatorname{cag} \mathrm{A}-\mathrm{AB}$ & 5 & 0 & 0.417 & 0 & 4 & 0.180 \\
\hline cagA-ABC & 3 & 0 & & 2 & 1 & \\
\hline cagA-ABD & 44 & 19 & & 14 & 50 & \\
\hline cagA-BD & 2 & 0 & & 0 & 2 & \\
\hline $\mathrm{vacA} s 1 \mathrm{c} / \mathrm{m} 1 \mathrm{~b}$ & 13 & 5 & 1.000 & 5 & 13 & 0.605 \\
\hline $\operatorname{vacA} \mathrm{s} 1 \mathrm{c} / \mathrm{m} 2$ & 36 & 12 & & 9 & 39 & \\
\hline $\mathrm{vacA} \mathrm{s} 1 \mathrm{c} / \mathrm{m} 1 \mathrm{~b} / \mathrm{m} 2$ & 5 & 2 & & 2 & 5 & \\
\hline iceA1 & 41 & 17 & 0.146 & 12 & 46 & 0.679 \\
\hline iceA2 & 1 & 1 & & 0 & 2 & \\
\hline iceA1+iceA2 & 12 & 1 & & 4 & 9 & \\
\hline
\end{tabular}

cagA, cytotoxin associated gene A; vacA, vacuolating cytotoxin A; iceA, induced by contact with epithelium gene A.

in Table III. No significant association between the vacA genotypes and clinical outcomes was identified $(\mathrm{P}=1.000)$. There was also no significant association between the vacA genotypes and age, place of residence (Guiyang city vs. Qiannan autonomous prefecture, urban vs. suburban), or ethnic group ( $\mathrm{P}=0.605, \mathrm{P}=0.400, \mathrm{P}=0.718$ and $\mathrm{P}=0.210$, respectively), as shown in Tables IV and V.

Polymorphism of iceA. The polymorphism of iceA genes was also assessed. Gel electrophoresis genotyping of $H$. pylori ice $\mathrm{A} 1$ and iceA 2 alleles is shown in Fig. $1 \mathrm{E}$ and $\mathrm{F}$, respectively. Among the 73 cases, the iceA1 and iceA2 genotypes were present in $79.45 \%(58 / 73)$ and $2.74 \%$ (2/73), respectively. The iceA1/iceA 2 mixed genotype occurred in $17.81 \%(13 / 73)$ of cases. The distribution of iceA genotypes in Guizhou province is shown in Table III. No significant association was found between iceA genotypes and disease outcomes, age, place of residence (Guiyang city, vs. Qiannan autonomous prefecture, urban vs. suburban), or ethnic group $(\mathrm{P}=0.146, \mathrm{P}=0.679$, $\mathrm{P}=0.304, \mathrm{P}=0.884$ and $\mathrm{P}=0.621$, respectively), as shown in Tables IV and V.

EPIYA motifs of cagA. As described above, the EPIYA motif patterns were determined for each strain. A comparison of the results indicated that the EPIYA genotypes of the 500, 600,610 and $550 \mathrm{bp}$ amplicons were these of the cag A-AB, $-\mathrm{ABC},-\mathrm{ABD}$ and $-\mathrm{BD}$ genotypes, respectively. The structural polymorphism of the cagA amino acid sequence is shown in Fig. 2. It was noted that cagA EPIYA-ABD (63/73, 86.30\%) was the predominant genotype in the present study, followed by cagA-AB (5/73, 6.85\%), cagA-ABC (3/73, 4.11\%) and cagA-BD $(2 / 73,2.74 \%)$. The distribution of cag A genotypes in Guizhou province is shown in Table III. However, statistical analysis revealed no significant correlation between the disease outcome and the cagA genotypes $(\mathrm{P}=0.417)$. There was also no significant correlation between the cagA genotypes and age, place of residence (Guiyang city, vs. Qiannan autonomous prefecture, urban vs. suburban), or ethnic group $(\mathrm{P}=0.180, \mathrm{P}=0.845, \mathrm{P}=0.602$ and $\mathrm{P}=1.000$, respectively), as shown in Tables IV and V.

The results of phylogenetic tree cluster analysis of the cagA carboxyl terminal variable region is shown in Fig. 3.
There was a clustering association between western-type cagA-AB and cagA-ABC; there was also a clustering association between East Asian-type cagA-ABD and cagA-BD. All five strains with western-type cag A-AB and three strains with western-type cagA-ABC were isolated from patients with chronic gastritis; 19 strains with East Asian-type cagA-ABD were isolated from patients with peptic ulcers, and a further 46 with East Asia-type cagA were isolated from patients with chronic gastritis. As mentioned above, it appeared that East Asia-type cagA strains may exhibit higher virulence than western-type cagA strains.

The frequencies of the four EPIYA or EPIYA-like motifs are shown in Table VI. In total, 212 EPIYA motifs were obtained from 73 cagA sequences. The most frequent EPIYA motif was EPIYA $(197 / 212,92.92 \%)$, followed by EPIYT $(8 / 212$, $3.77 \%)$, ESIYA $(6 / 212,2.83 \%)$ and ESIYT $(1 / 212,0.47 \%)$. The EPIYA-B motif had a high degree of variation in the five amino acids (EPIYA, EPIYT, ESIYA or ESIYT). In addition, 15 EPIYA-like motifs (EPIYT, ESIYA, ESIYT) were isolated from patients with gastritis.

\section{Discussion}

H.pylori is well known for its genetic diversity and geographical differences, which may be associated with compound clinical disease outcomes (7). In the present study, the epidemiological characteristics of major virulence genes of $H$. pylori were investigated in Guizhou province. H. pylori was cultured from clinical samples, and virulence genotypes of cagA, vacA and iceA were examined by PCR assays. The results showed the prevalent strains of $H$. pylori in Guizhou province were cagA-positive, vacA s1c/m2-positive and iceA-positive. The results describe the prevalence of $H$. pylori strains in Guizhou province between January 2015 and December 2016, and provides an experimental basis for molecular epidemiological investigations of $H$. pylori in this region.

Epidemiological investigations have shown that the cagA genotype varies markedly worldwide. The prevalence of cag A among $H$.pylori in different regions varies between 50 and $60 \%$ in certain western countries to almost $100 \%$ in East Asia (19). In the present study, it was shown that cagA genotypes were 
Table V. Distribution of cagA genotypes by place of residence and ethnicity of patients.

Place of residence

\begin{tabular}{|c|c|c|c|c|c|c|c|c|c|}
\hline \multirow[b]{3}{*}{ Genotype } & & \multirow{2}{*}{\multicolumn{3}{|c|}{ Ethnic group }} \\
\hline & & & & & & & & & \\
\hline & city & autonomous prefecture & P-value & Urban & Suburban & P-value & Han & Minority & P-value \\
\hline CagA-AB & 5 & 0 & 0.845 & 3 & 2 & 0.602 & 4 & 1 & 1.000 \\
\hline CagA-ABC & 3 & 0 & & 2 & 1 & & 3 & 0 & \\
\hline cagA-ABD & 50 & 13 & & 25 & 38 & & 51 & 12 & \\
\hline CagA-BD & 2 & 0 & & 1 & 1 & & 2 & 0 & \\
\hline $\operatorname{vacA} \mathrm{s} 1 \mathrm{c} / \mathrm{m} 1 \mathrm{~b}$ & 13 & 5 & 0.400 & 7 & 11 & 0.718 & 13 & 5 & 0.210 \\
\hline $\operatorname{vacA} \mathrm{s} 1 \mathrm{c} / \mathrm{m} 2$ & 41 & 7 & & 22 & 26 & & 42 & 6 & \\
\hline $\mathrm{vacA} \mathrm{s} 1 \mathrm{c} / \mathrm{m} 1 \mathrm{~b} / \mathrm{m} 2$ & 6 & 1 & & 2 & 5 & & 5 & 2 & \\
\hline iceA1 & 49 & 9 & 0.304 & 24 & 34 & 0.884 & 46 & 12 & 0.621 \\
\hline iceA2 & 1 & 1 & & 1 & 1 & & 2 & 0 & \\
\hline iceA1/iceA2 & 10 & 3 & & 6 & 7 & & 12 & 1 & \\
\hline
\end{tabular}

cagA, cytotoxin associated gene A; vacA, vacuolating cytotoxin A; iceA, induced by contact with epithelium gene A.

Table VI. Frequencies of EPIYA motifs.

\begin{tabular}{|c|c|c|c|c|c|}
\hline Motif type & EPIYA & EPIYT & ESIYA & ESIYT & Total \\
\hline \multicolumn{6}{|c|}{ All cagA type } \\
\hline All motifs & 197 & 8 & 6 & 1 & \multirow[t]{5}{*}{212} \\
\hline A motifs & 71 & 0 & 0 & 0 & \\
\hline B motifs & 59 & 7 & 6 & 1 & \\
\hline $\mathrm{C}$ motifs & 2 & 1 & 0 & 0 & \\
\hline D motifs & 65 & 0 & 0 & 0 & \\
\hline \multicolumn{6}{|c|}{ Western-type-ABC } \\
\hline All motifs & 5 & 4 & 0 & 0 & \multirow[t]{4}{*}{9} \\
\hline A motifs & 3 & 0 & 0 & 0 & \\
\hline B motifs & 0 & 3 & 0 & 0 & \\
\hline $\mathrm{C}$ motifs & 2 & 1 & 0 & 0 & \\
\hline \multicolumn{6}{|c|}{ Eastern-type-ABD } \\
\hline All motifs & 181 & 2 & 5 & 1 & \multirow[t]{4}{*}{189} \\
\hline A motifs & 63 & 0 & 0 & 0 & \\
\hline B motifs & 55 & 2 & 5 & 1 & \\
\hline D motifs & 63 & 0 & 0 & 0 & \\
\hline \multicolumn{6}{|c|}{ Western-type-AB } \\
\hline All motifs & 7 & 2 & 1 & & \multirow[t]{3}{*}{10} \\
\hline A motifs & 5 & 0 & 0 & & \\
\hline B motifs & 2 & 2 & 1 & & \\
\hline \multicolumn{6}{|c|}{ Eastern-type-BD } \\
\hline All motifs & 4 & 0 & 0 & & \multirow[t]{3}{*}{4} \\
\hline B motifs & 2 & 0 & 0 & & \\
\hline D motifs & 2 & 0 & 0 & & \\
\hline
\end{tabular}

cagA, cytotoxin associated gene A.

detected in all strains in Guizhou province. In another study in this region, Zhou et al reported that $30 \mathrm{H}$. pylori strains isolated from gastric cancer were cagA-positive, with cagA having a positive rate of $100 \%$ (35), which was consistent with the results of the present study. The vacA genotypes also vary geographically. The vacA sla genotype is common in South Asia, the slb genotype is common in Latin America and Africa, and s1c is common in East Asia (24,36,37). The vacA $\mathrm{m} 1$ genotype is common in North Asian countries, including Japan and South Korea, whereas the $\mathrm{m} 2$ genotype is predominant in Southeast Asia, including Taiwan, China and Vietnam (20). The results of the present study showed that the predominant vacA genotype was s1c/m2 in Guizhou province. Notably, the iceA genotype also varies among different regions. A previous meta-analysis showed that the prevalence of iceA1 was significantly higher in East Asian countries than in western countries, whereas the prevalence of iceA2 was higher in western countries than in East Asian countries (26). Consistent with this finding, the iceA1 genotype was predominant in Guizhou province in the present study.

Although Guizhou province is a multi-ethnic society, there was no ethnic specificity of $H$.pylori infection. This differs from Malaysia, which has three major ethnic groups, namely, Malay, Chinese and Indian; vacA sla/m2 has been detected in all of these ethnic groups, whereas vacA $\mathrm{s} 1 \mathrm{c} / \mathrm{m} 2$ was only isolated from Chinese patients (38). Therefore, vacA genotypes were associated with ethnic groups in Malaysia. In the present study, as no predictive value of these $H$. pylori virulence genes was identified in Guizhou province, there may be no need to classify patients according to ethnicity during treatment, with patients of different ethnicities offered the same diagnosis and treatment strategies.

H. pylori infection can result in compound gastroduodenal diseases, including gastritis, peptic ulcer and gastric carcinoma. The present study did not find an association between $H$. pylori virulence diversity and clinical disease outcomes in the Guizhou region. Zhou et al reported that $H$. pylori infection may induce the demethylation of lactate dehydrogenase, dihydrolipoamide dehydrogenase and calmodulin genes, and increase methylation of the Ran-specific GTPase-activating protein gene, which leads to dysfunctional gene expression in gastric cancer tissues and cells (35). A number of reports have shown that infection with 


$$
\text { EPIYA-A EPIYA-B }
$$

\begin{tabular}{|c|c|c|c|}
\hline \multirow[t]{2}{*}{$\begin{array}{l}\text { Western-type CagA } \\
\text { EPIYA-AB }\end{array}$} & \multicolumn{3}{|c|}{ 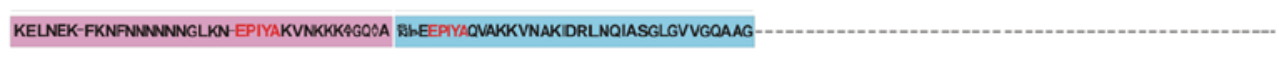 } \\
\hline & EPIYA-A & EPIYA-B & EPIYA-C \\
\hline \multicolumn{4}{|c|}{$\begin{array}{l}\text { Western-type CagA KELNEK-FKNFNNWNNNGLKN EPIYAKVNKKKAGQSA NbEEPYAQVAKKVNAKIDRLNQIASGLGVVGQAAG FPLKFHDKVDOLSKVVLSASPEPIYATIDLLGGPFPLKRHDKVDOLSKVG } \\
\text { EPIYA-ABC }\end{array}$} \\
\hline \multirow{2}{*}{$\begin{array}{c}\text { East Asia-type CagA } \\
\text { EPIYA-ABD }\end{array}$} & KELMEKLFGHSWNANGUWNNEEPYAEVN & QVAKKVSAKDDQLNEATS & SGAGESASPEPIYATIDFDEANQAGFPLRRVACVNOLSKVG \\
\hline & EPIYA-A & EPIYA-B & EPIYA-D \\
\hline \multirow{2}{*}{$\begin{array}{c}\text { East Asia-type CagA } \\
\text { EPIYA-BD }\end{array}$} & & QVAKKVSAKIDQLNEATS & SGAGSSASPEPIYATIDFDEANQAGFPLRRPAAVNOLSKVG \\
\hline & & EPIYA-B & EPIYA-D \\
\hline
\end{tabular}

Figure 2. Structural polymorphism in the cagA amino acid sequence of East Asian-type and western-type cagA. cagA, cytotoxin associated gene A.

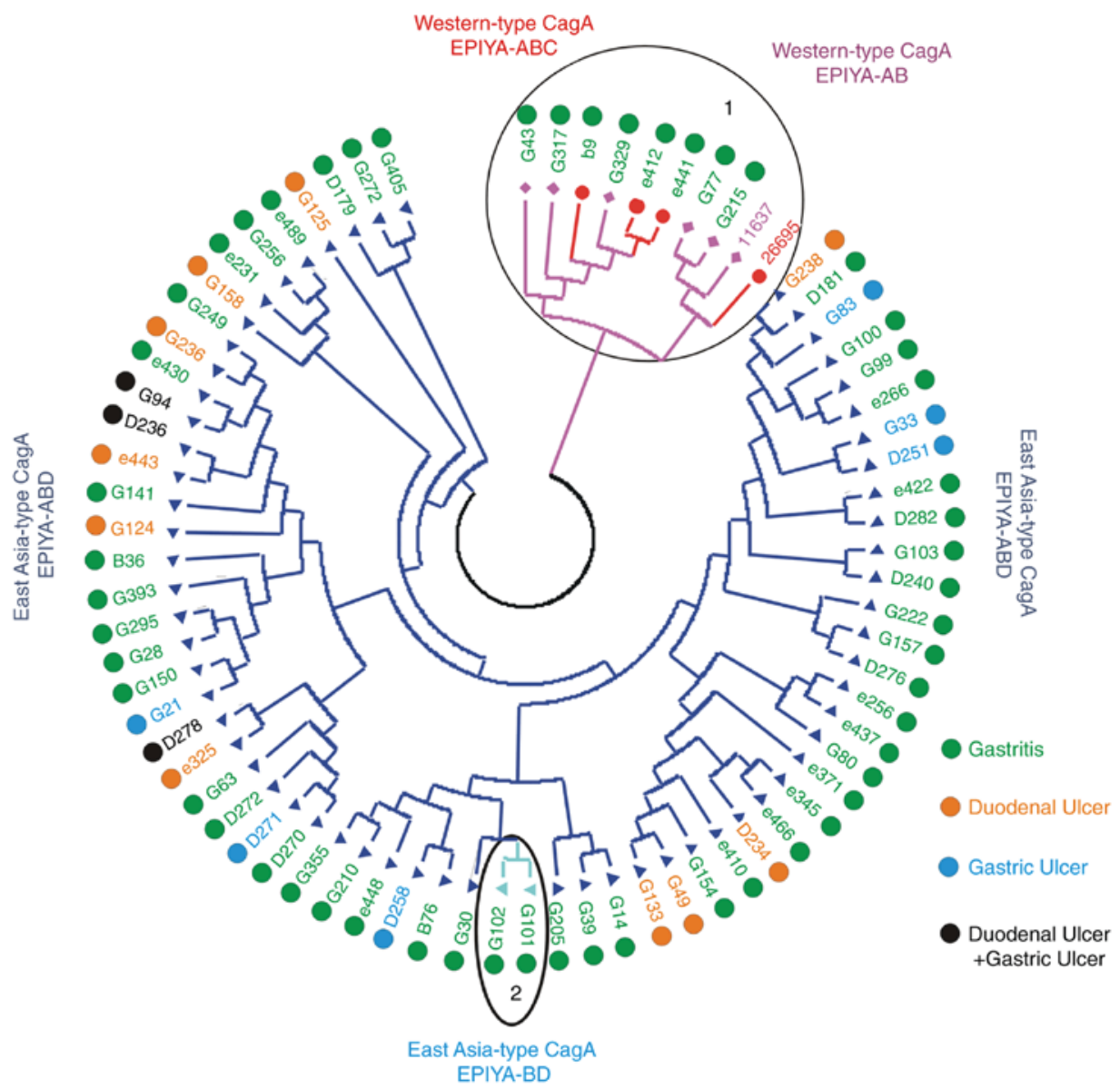

Figure 3. Phylogenetic tree cluster analysis of the cagA carboxyl terminal variable region. On the inner side of the phylogenetic tree, red branches are western-type cag A-ABC (indicated in circle 1); purple branches are western-type cagA-AB (circle 1); blue branches are East Asia-type cagA-ABD; cyan branches are East Asia-type cagA-BD (circle 2). On the outer side of the phylogenetic tree, green circles are gastritis; orange circles are for duodenal ulcer; blue circles are for gastric ulcer; black circles are for compound ulcer, including duodenal ulcer and gastric ulcer. cagA, cytotoxin associated gene A.

a higher number of cagA EPIYA-C motif strains was associated with increased gastric inflammation and atrophy in western countries (39-41). However, the genetic diversity of $H$. pylori virulence genes is not associated with disease progression in certain eastern countries $(9,16)$. Matsunari et al reported that, in the Bhutan region, 209 isolate strains, in which $>50 \%$ of the strains had multiple EPIYA motifs repeats in East Asian-type cagA-ABD, are associated with atrophic gastritis and gastric cancer (42). An association between vacA genotypes and gastric precancerous or gastric carcinoma was observed in Brazil (39). However, no correlation has been found between vacA genotypes and diseases in Japan or Sweden $(9,41)$. Additionally, an association has been reported between the iceA1 genotype and peptic ulcers, and the iceA2 genotype and gastritis (26). Among the 73 isolates in the present study, no association was found between the iceA1 or iceA2 genotypes and clinical disease outcomes.

Among the 73 patients, none were diagnosed with gastric cancer; only 14 gastric biopsy samples were obtained from 
patients with gastric cancer at the First Affiliated Hospital of Guizhou Medical University and the People's Hospital of Qiannan Autonomous Prefecture between January and December 2016, however, H. pylori isolation was negative. This may be associated with reduced Helicobacter abundance and overrepresentation of bacterial genera.

Current knowledge of bacteria other than H.pylori in the human stomach remains limited. The investigation of the gastric microbiota in healthy individuals or disease states is lacking due to limitations of culture conditions and the collection of gastric mucosal specimens. With the development of molecular biology and bacterial 16S rRNA gene identification technology, the constitution and diversity of gastric flora has been gradually identified. Notably, You et al reported a microarray used to compare the genomic profiles of strains isolated from patients with gastroduodenal diseases in the Heilongjiang province of China, and their findings may provide insight into novel biomarkers for the prediction of gastric diseases (43). Novel genetic variations may be examined in our future investigations using similar approaches. The gastric flora may be important roles in human health and disease, which remain to be elucidated. The composition of the gastric flora is dynamic and affected by several factors, including $H$. pylori infection and combination therapy with antibiotics and proton pump inhibitors. The gastric flora may also affect the development of gastric diseases following $H$. pylori colonization. $H$. pylori infection in Guizhou province may lead to various diseases without specificity. This may be explained by gastric flora in the stomach of local residents. Finally, the clarification of genotypes of gastric flora from different areas may facilitate clinical therapeutics.

\section{Acknowledgements}

The authors would like to thank Professor Jie Yang, Professor Yonghong Zhang, and Dr Chen Pan from the Department of Gastrointestinal medicine (The First Affiliated Hospital of Guizhou Medical University) for case selection.

\section{Funding}

This study was supported by the National Natural Science Foundation of China (grant no. 81460314).

\section{Availability of data and materials}

All data generated or analyzed during this study are included in this published article.

\section{Authors' contributions}

ZC conceived, designed and supervised the experiments. LY, FL, CG and QW performed the experiments. KP, LX, YX and YC collected the samples. ZC and LY performed the data analysis and wrote the manuscript. All authors read and approved the final manuscript.

\section{Ethics approval and consent to participate}

All protocols were approved by the Ethical Committee of the First Affiliated hospital of Guizhou Medical University.
All procedures contributing to the study complied with the Declaration of Helsinki. Written informed consent was obtained from all patients.

\section{Patient consent for publication}

Not applicable.

\section{Competing interests}

The authors declare that they have no competing interests.

\section{References}

1. Pereira WN, Ferraz MA, Zabaglia LM, de Labio RW, Orcini WA, Bianchi Ximenez JP, Neto AC, Payão SL and Rasmussen LT: Association among $\mathrm{H}$. pylori virulence markers dupA, cagA and vacA in Brazilian patients. J Venom Anim Toxins Incl Trop Dis 20: 1, 2014

2. Wang HP, Zhu YL and Shao W: Role of Helicobacter pylori virulence factor cytotoxin-associated gene A in gastric mucosa-associated lymphoid tissue lymphoma. World J Gastroenterol 19: 8219-8226, 2013.

3. Krisch LM, Posselt G, Hammerl P and Wessler S: CagA phosphorylation in Helicobacter pylori-infected B cells is mediated by the non-receptor tyrosine kinases of the $\mathrm{Src}$ and $\mathrm{Abl}$ families. Infect Immun 84: 2671-2680, 2016.

4. Hashinaga M, Suzuki R, Akada J, Matsumoto T, Kido Y, Okimoto T, Kodama M, Murakami K and Yamaoka Y: Differences in amino acid frequency in CagA and VacA sequences of Helicobacter pylori distinguish gastric cancer from gastric MALT lymphoma. Gut Pathog 8: 54, 2006.

5. Zhang M, Zhou YZ, Li XY, Tang Z, Zhu HM, Yang Y and Chhetri JK: Seroepidemiology of Helicobacter pylori infection in elderly people in the Beijing region, China. World J Gastroenterol 20: 3635-3639, 2014

6. Ahn HJ and Lee DS: Helicobacter pylori in gastric carcinogenesis. World J Gastrointest Oncol 7: 455-465, 2015.

7. Datta De D and Roychoudhury S: To be or not to be: The host genetic factor and beyond in Helicobacter pylori mediated gastro-duodenal diseases. World J Gastroenterol 21: 2883-2895, 2015.

8. Myint T, Shiota S, Vilaichone RK, Ni N, Aye TT, Matsuda M, Tran TT, Uchida T, Mahachai V and Yamaoka Y: Prevalence of Helicobacter pylori infection and atrophic gastritis in patients with dyspeptic symptoms in Myanmar. World J Gastroenterol 21: 629-636, 2015.

9. Kita M, Yokota K, Okada H, Take S, Takenaka R, Kawahara Y, Oguma K, Matsushita $\mathrm{O}$ and Yamamoto K: The genetic diversity of Helicobacter pylori virulence genes is not associated with gastric atrophy progression. Acta Med Okayama 67: 93-98, 2013.

10. Figura N, Marano L, Moretti E and Ponzetto A: Helicobacter pylori infection and gastric carcinoma: Not all the strains and patients are alike. World J Gastrointest Oncol 8: 40-54, 2016.

11. Jiménez-Soto LF and Haas R: The CagA toxin of Helicobacter pylori: Abundant production but relatively low amount translocated. Sci Rep 6: 23227, 2016.

12. Patra R, Chattopadhyay S, De R, Datta S, Chowdhury A, Ramamurthy T, Nair GB, Berg DE and Mukhopadhyay AK: Intact cag pathogenicity island of Helicobacter pylori without disease association in Kolkata, India. Int J Med Microbiol 301: 293-302, 2011.

13. Senda Y, Murata-Kamiya N and Hatakeyama M: C-terninal Src kinase-mediated EPIYA phosphorylation of pragmin creates a feed-forward C-terminal Src kinase activation loop that promotes cell motility. Cancer Sci 107: 972-980, 2016.

14. Sicinschi LA, Correa P, Peek RM, Camargo MC, Piazuelo MB Romero-Gallo J, Hobbs SS, Krishna U, Delgado A, Mera R, et al: CagA C-terminal variations in Helicobacter pylori strains from Colombian patients with gastric precancerous lesions. Clin Microbiol Infect 16: 369-378, 2010.

15. Furuta Y, Yahara K, Hatakeyama M and Kobayashi I: Evolution of cagA oncogene of Helicobacter pylori through recombination. PLoS One 6: e23499, 2011. 
16. Chang CC, Kuo WS, Chen YC, Perng CL, Lin HJ and Ou YH: Fragmentation of CagA reduces hummingbird phenotype induction by Helicobactor pylori. PLoS One 11: e0150061, 2016.

17. Jones KR, Joo YM, Jang S, Yoo YJ, Lee HS, Chung IS, Olsen CH, Whitmire JM, Merrell DS and Cha JH: Polymorphism in the CagA EPIYA motif impacts development of gastric cancer. J Clin Microbiol 47: 959-968, 2009.

18. Braga LL, Oliveira MA, Gonçalves MH, Chaves FK, Benigno TG, Gomes AD, Silva CI, Anacleto C, Batista Sde A and Queiroz DM: CagA phosphorylation EPIYA-C motifs and the vacA i genotype in Helicobacter pylori strains of asymptomatic children from a high-risk gastric cancer area in northeastern Brazil. Mem Inst Oswaldo Cruz 109: 1045-1049, 2014.

19. Yamaoka Y: Mechanisms of disease: Helicobacter pylori virulence factors. Nat Rev Gastroenterol Hepatol 7: 629-641, 2010.

20. Shiota S, Suzuki R and Yamaoka Y: The significance of virulence factors in Helicobacter pylori. J Dig Dis 14: 341-349, 2013.

21. Wen S and Moss SF: Helicobacter pylori virulence factors in gastric carcinogenesis. Cancer Lett 282: 1-8, 2009.

22. Utsch $\mathrm{C}$ and Haas R: VacA's induction of VacA-containing vacuoles (VCVs) and their immunomodulatory activities on human T cells. Toxins (Basel) 8: E190, 2016.

23. Amilon KR, Letley DP, Winter JA, Robinson K and Atherton JC: Expression of the Helicobacter pylori virulence factor vacuolating cytotoxin $\mathrm{A}(\mathrm{vacA})$ is influenced by apotential stem-loop structure in the 5'untranslated region of the transcript. Mol Microbiol 98: 831-846, 2015.

24. Yamaoka Y and Graham DY: Helicobacter pylori virulence and cancer pathogenesis. Future Oncol 10: 1487-1500, 2014.

25. Thi Huyen Trang T, Thanh Binh T and Yamaoka Y: Relationship between vacA Tyeps and development of gastroduodenal diseases. Toxins (Basel) 8: E182, 2016.

26. Shiota S, Watada M, Matsunari O, Iwatani S, Suzuki R and Yamaoka Y: Helicobacter pylori iceA, clinical outcomes, and correlation with cagA: A meta-analysis. PLoS One 7: e30354, 2012.

27. Roesler BM, Rabelo-Goncalves EM and Zeitune JM: Virulence factors of Helicobacter pylori: A review. Clin Med Insights Gastroenterol 7: 9-17, 2014

28. Ben Mansour K, Fendri C, Zribi M, Masmoudi A, Labbene M, Fillali A, Ben Mami N, Najjar T, Meherzi A, Sfar R and Burucoa C: Prevalence of Helicobacter pylori vacA, cagA, iceA and oipA genotypes in Tunisian patients. Ann Clin Microbiol Antimicrob 9: 10, 2010 .

29. Miftahussurur M, Syam AF, Makmun D, Nusi IA, Zein LH, Zulkhairi, Akil F, Uswan WB, Simanjuntak D, Uchida T, et al: Helicobacter pylori virulence genes in the five largest islands of Indonesia. Gut Pathog 7: 26, 2015.

30. da Coata DM, Pereira Edos S and Rabenhorst SH: What exists beyond cagA and vacA? Helicobacter pylori genes in gastric diseases. World J Gastroenterol 21: 10563-10572, 2015.

31. Xie JH, Chen YL, Wu QH, Wu J, Su JY, Cao HY, Li YC, Li YS, Liao JB, Lai XP, et al: Gastroprotective and anti-Helicobacter pylori potential of herbal formula HZJW: Safety and efficacy assessment. BMC Complement Altern Med 13: 119, 2013.
32. Secka O, Antonio M, Berg DE, Tapgun M, Bottomley C, Thomas V, Walton R, Corrah T, Thomas JE and Adegbola RA: Mixed infection with cagA positive and cagA negative strains of Helicobacter pylori lowers disease burden in The Gambia. PLoS One 6: e27954, 2011.

33. Secka O, Antonio M, Tapgun M, Berg DE, Bottomley C, Thomas V, Walton R, Corrah T, Adegbola RA and Thomas JE: PCR-based genotyping of Helicobacter pylori of Gambian children and adults directly from biopsy specimens and bacterial cultures. Gut Pathog 3: 5, 2011

34. Yamazaki S, Yamakawa A, Okuda T, Ohtani M, Suto H, Ito Y, Yamazaki Y, Keida Y, Higashi H, Hatakeyama M and Azuma T: Distinct diversity of vacA, cagA, and cagE genes of Helicobacter pylori associated with peptic ulcer in Japan. J Clin Microbiol 43: 3906-3916, 2005.

35. Zhou J, Wang W, Xie Y, Zhao Y, Chen X, Xu W, Wang Y and Guan Z: Proteomics-based identification and analysis of proteins associated with Helicobacter pylori in gastric cancer. PLoS One 11: e0146521, 2016.

36. Dabiri H, Maleknejad P, Yamaoka Y, Feizabadi MM, Jafari F, Rezadehbashi M, Nakhjavani FA, Mirsalehian A and Zali MR: Distribution of Helicobacter pylori cagA, cagE, oipA and vacA in different major ethnic groups in Tehran, Iran. J Gastroenterol Hepatol 24: 1380-1386, 2009

37. Camorlinga-Ponce M, Perez-Perez G, Gonzalez-Valencia G, Mendoza I, Peñaloza-Espinosa R, Ramos I, Kersulyte D, Reyes-Leon A, Romo C, Granados J, et al: Helicobacter pylori genotyping from American indigenous groups shows novel Amerindian vacA and cagA alleles and Asian, African and European admixture. PLoS One 6: e27212, 2011.

38. Alfizah H, Rukman AH, Norazah A, Hamizah R and Ramelah M: Ethnicity association of Helicobacter pylori virulence genotype and metronidazole susceptibility. World J Gastroenterol 19: 1283-1291, 2013

39. Queiroz DM, Silva CI, Goncalves MH, Braga-Neto MB Fialho AB, Fialho AM, Rocha GA, Rocha AM, Batista SA, Guerrant RL, et al: Higher frequency of cagA EPIYA-C phosphorylation sites in $\mathrm{H}$. pylori strains from first-degree relatives of gastric cancer patients. BMC Gastroenterol 12: 107, 2012.

40. Batista SA, Rocha GA, Rocha AM, Saraiva IE, Cabral MM, Oliveira RC and Queiroz DM: Higher number of Helicobacter pylori CagA EPIYA C phosphorylation sites increases the risk of gastric cancer, but not duodenal ulcer. BMC Microbiol 11: 61, 2011.

41. Karlsson A, Ryberg A, Dehnoei MN, Borch K and Monstein HJ: Association between cagA and vacA genotypes and pathogenesis in a Helicobacter pylori infected population from South-eastern Sweden. BMC Microbiol 12: 129, 2012.

42. Matsunari O, Miftahussurur M, Shiota S, Suzuki R, Vilaichone RK, Uchida T, Ratanachu-ek T, Tshering L, Mahachai V and Yamaoka Y: Rare Helicobacter pylori virulence genotypes in Bhutan. Sci Rep 6: 22584, 2016.

43. You Y, He L, Zhang M, Fu J, Gu Y, Zhang B, Tao X and Zhang J: Comparative genomics of Helicobacter pylori strains of China associated with different clinical outcome. PLoS One 7: e38528, 2012. 